\title{
Analisis Implementasi Transformasi Bisnis Peternakan terhadap Kinerja PT Berdikari (PERSERO)
}

\section{The Analysis of Animal Husbandry Business Transformation Implementation toward Performance of PT Berdikari (PERSERO)}

\author{
Anna Muslikhah Jamil ${ }^{1 *}$, Harianto $^{2}$, Sahara $^{3}$ \\ ${ }^{1)}$ Kementerian BUMNJl. Medan Merdeka Selatan No. 13 Jakarta 10110 \\ ${ }^{2}$ Departemen Agribisnis, Fakultas Ekonomi dan Manajemen-IPB \\ ${ }^{3)}$ Departemen Ilmu Ekonomi, Fakultas Ekonomi dan Manajemen-IPBJl. Kamper Wing 4 Level 5 Kampus IPB, Bogor 16680
}

\begin{abstract}
PT Berdikari (Persero) was transformed into an Animal Husbandry State Owned Company (SOE) in 2012 through the letter of State-Owned Enterprises Minister Number S-211/D1.MBU/2012 to support Government's policies on providing animal food supply. This business transformationchanges core competencies from trading agribusiness commodities (rice, sugar, meat, platantion commodities, fertilizer, insurance, etc.) to animal husbandry. It becomes corporate transformation phase that cause financial performance anomalies. This study aims to identify the effect of business transformation towards financial performance of PT Berdikari (Persero) using statistical hypothesis testing by T-test to explore the existence of financial performance impact before and after business transformation practice. Based on State-Owned Enterprises Minister Regulation Number 1000/MBU/2012 about SOE performance assessment, there are eight indicators for assessing SOEs' financial performance: Return on Equity (ROE), Return on Investment (ROI), Inventory Turn Over, Colection Period, Cash Ratio, Current Ratio, Total Turn Over and Capital to Total Assets Ratio. The result of hypothesis testing with $95 \%$ degree of significance found that there are differences of ROE and Inventory Turn Over PT Berdikari (Persero) before and after transformation. Company profit was decreased and operating expenses was increased. Low level of sales revenue drives ROE, especially after business transformation. This low level of sales caused Inventory Turn Over to increased since inventories in the warehouse was cumulated.
\end{abstract}

Keywords: Animal husbandry business, business transformation, BUMN, financial performance.

\begin{abstract}
ABSTRAK
Pada tahun 2012 PT Berdikari (Persero) bertransformasi menjadi BUMN Peternakan melalui surat Menteri BUMN Nomor S-211/D1.MBU/2012 untuk mendukung kebijakan pemerintah dalam penyediaan pangan hewani. Transformasi bisnis ini mengubah kompetensi bisnis inti dari perdagangan umum (beras, gula, daging, komoditi perkebunan, pupuk, asuransi dan lain-lain) ke bisnis peternakan. Kondisi tersebut berpengaruh pada anomali kinerja keuangan perusahaan. Tujuan penelitian ini yaitu menganalisis pengaruh implementasi transformasi bisnis terhadap pencapaian kinerja keuangan PT Berdikari (Persero). Analisis dilakukan melalui pengujian hipotesis menggunakan Uji Beda (Uji T) untuk mengetahui ada/tidak ada pengaruh kinerja keuangan sebelum dan sesudah penerapan transformasi bisnis. Berdasarkan peraturan Menteri BUMN Nomor 100/MBU/2012 tentang penilaian kinerja BUMN terdapat delapan indikator yang digunakan untuk mengukur kesehatan perusahaan BUMN dari aspek kinerja keuangan yakni: Return of Equity, Return of Invesment, Inventory Turn Over, Colection Period, Cash Ratio, Current Ratio, Total Turn Over dan Total Modal Terhadap Asset Sendiri. Dari hasil uji hipotesa dengan signifikansi 95\%, terdapat perbedaan pada $R O E$ dan Inventory Turn OverPT Berdikari (Persero) mengalami penurunan kinerja keuangan sebelum dan setelah transformasi. Hal ini ditandai dengan penurunan laba perusahaan dan tingginya beban operasional perusahaan, dan rendahnya penjualan mempengaruhi kenaikan nilai $R O E$ khususnya setelah transformasi bisnis diimplementasikan. Rendahnya penjualan menyebabkan naiknya nilai Inventory Turn Over akibat terjadinya penumpukan barang persediaan digudang yang cukup besar.
\end{abstract}

Kata kunci: Bisnis peternakan, BUMN, kinerja keuangan, transformasi bisnis.

*Corresponding author

Alamat e-mail: aquanamj@yahoo.co.id 


\section{PENDAHULUAN}

PT Berdikari (Persero) ditunjuk oleh Pemerintah Republik Indonesia sebagai BUMN bidang peternakan melalui surat Menteri BUMN Nomor S-211/D1.MBU/2012 dengan tugas utama mendukung ketersediaan sumber pangan hewani nasional yang bermutu dan terjangkau. Kebijakan tersebut merupakan upaya intervensi pemerintah untuk meningkatkan kinerja perusahaan yang cenderung stagnan sebelum tahun 2012. PT Berdikari (Persero)melakukan transformasi dengan mengubah bisnis inti dari perdagangan umum (komoditi pertanian,rempahrempah, pupuk dan logistik) ke bisnis peternakan. Menurut Moeljono (2004), salah satu bentuk transformasi yaitu restrukturisasi atau program peningkatan daya saing BUMN melalui penajaman fokus bisnis, perbaikan skala usaha dan penciptaan core competencies. Penunjukkan PT Berdikari (Persero) sebagai BUMN bidang peternakan merupakan upaya perbaikan kinerja dan mengarahkan bisnis pada core competencies peternakan. Kementerian BUMN sebagai pemegang saham memiliki tugas melakukan pembinaan kepada BUMN agar menjadi kelas dunia, untuk ituPT Berdikari (Persero) dalam menjalankan aktivitas bisnisnya di bidang peternakan perlu menyelaraskan dengan program pemerintah termasuk menjalankan penugasan pemerintah (Dibyo, 2004).

Dalam rangka menjalankan peran strategis tersebut, perusahaan harus berkinerja baik dan memenuhi Good Corporate Governance. Kinerja keuangan PT Berdikari (Persero) belum sehat, kondisi tersebut menjadi tantangan bagi perusahaan untuk memenuhi harapan pemegang saham bahwa penguatan fokus bisnis peternakan akan mampu memperbaiki kinerja keuangan perusahaan. Tujuan utama penugasan kepada PT Berdikari (Persero) yaitu untuk memperbaiki kinerja serta memaksimalkan sumberdaya yang ada. Dinamika tersebut perlu menjadi perhatian Direksi dan manajemen perusahaan sebagai bahan pertimbangan dalam perencanaan dan manajemen risiko dalam jangka pendek, menengah maupun panjang terutama dari aspek keuangan.

Berdasarkan Peraturan menteri BUMN Nomor PER 100/MBU/2002, terdapat tiga aspek yang diukur untuk mengetahui tingkat kesehatan perusahaan, yakni: aspek keuangan, aspek operasional dan aspek administrasi. Untuk mengetahui kinerja perusahaan, penulis hanya meneliti pada aspek keuangannya saja. Oleh karena itu, perlu dilakukan identifikasi untuk mengetahui pengaruh transformasi pada kinerja perusahaan dari aspek keuangan dengan mengukur rasio likuiditas, rasio solvabilitas dan profitabilitas menggunakan delapan indikator kinerja keuangan sebelum dan setelah transformasi diterapkan (Mujiyanto, 2012). Dan untuk menilai keberhasilan kinerja perlu dilakukan evaluasi data keuangan sebelum dan setelah diterapkannya transformasi (Kesi\& Budiati, 2009). Untuk itu kondisi keuangan perusahaan pada periode sebelum penunjukkan sebagai BUMN peternakan yaitu sebelum tahun 2012 perlu diidentifikasi ada/tidaknya perbedaan dengan periode setelah tahun 2012. Fokus penelitian ini untuk mengetahui ada/tidaknya pengaruh perbaikan kinerja keuangan PT Berdikari (Persero) periode tahun 2012-2017 dibandingkan dengan periode tahun 2007-2012. Berdasarkan hasilidentifikasi tersebut diharapkan dapat menjadi bahan informasi pengambilan keputusan dan penentuan kebijakan pengembangan bisnis peternakan bagi perusahaan.

Fergusson (2008) meneliti bahwa transformasi di perusahaan milik negara cenderung lebih sulit dan berpotensi menciptakan krisis.Sementara itu, Ammarel (1999)menemukan bahwa transformasi menjadi solusi untuk memperbaiki kondisi perusahaan yang terpuruk dan terkendala permasalahan internal manajemen.Ristandi (2013) melakukan kajian atas program transformasi bisnis yang sedang dan telah dilaksanakan PT Telekomunikasi Indonesia, Tbk. (Telkom) dengan melihat lebih jauh mengenai faktor pendorong yang menjadi dasar dilakukannya program transformasi. Hasil penelitian menunjukkan bahwa faktor pendorong eksternal menjadi faktor yang penting dan dominan bagi Telkom untuk memutuskan melakukan program transformasi. Selain itu transformasi Telkom merupakan sebuah perubahan transformasional karena melibatkan proses, sistem, orang dan budaya.Mujiyanto (2012) menjelaskan bahwa transformasi bisnis dipengaruhi oleh faktor eksternal maupun internal yang dapat mempengaruhi kinerja keuangan dan kesehatan perusahaan. Faktor eksternal berupa 
kemajuan teknologi, kebijakan liberalisasi serta peran strategis menjadi penyebab utama dilakukannya transformasi bisnis. Sarkar (2013)menganalisis transformasi bisnis di PT Telecom dan menjelaskan bahwa transformasi bisnis adalah perang kritis pada sebuah organisasi yang menyebabkan perubahan radikal yang menekan faktor ekternal. Oleh karena itu agar implementasi transformasi binis berjalan lancar, Triller (2011) menjelaskan pentingnya komunikasi pimpinan dalam menginternalisasi proses transformasi kepada bawahan.Menurut Nurpratama (2016),kinerja perusahaan secara signifikan juga dipengaruhioleh variabel knowledge management yang terdiridari variabelpeople, process and technology. Perubahan transformasi (transformational change) didefinisikan oleh Mulyadi (1997) sebagai perubahan mendalam yang menuntut cara baru untuk berfikir dan berperilaku. Perubahan ini mempunyai lingkup yang luas, tidak berhubungan dengan masa lalu, dan umumnya tidak dapat dikembalikan ke kondisi asal perubahan.

Penilaian kinerja adalah penentuan secara periodik efektivitas operasional suatu organisasi, bagian organisasi dan personilnya, berdasarkan sasaran, standar dan kriteria yang telah ditetapkan sebelumnya (Mulyadi, 2009). Pemerintah memiliki standar penilaian kinerja perusahaan BUMN yang tertuang dalam Keputusan Menteri BUMN Nomor KEP100/MBU/2002 tentang penilaian Tingkat Kesehatan Badan Usaha Milik Negara. Menurut Syamsudin (2009), analisa rasio dapat digunakan sebagai alat untuk meramalkan keadaan keuangan serta hasil usaha di masa yang akan datang. Penilaian kinerja aspek keuangan dilakukan dengan analisis rasio keuangan (Sartono 2011), yang dilakukan dengan mengukur:

1. Rasio profitabilitas untuk mengetahui efisiensi perusahaan dalam menjalankan operasi dan menggunakan asetnya melalui tiga indikator yaitu Profit Margin, Return on Assets (ROA), dan Return on Equity (ROE);

2. Rasio likuiditas untuk mengetahui kemampuan perusahaan membayar kewajiban jangka pendek melalui tiga indikator yaitu Current Ratio, Quick Ratio dan Cash Ratio;

3. Rasio solvabilitas atau leverage untuk mengetahui kemampuan perusahaan membayar kewajiban jangka panjangnya melalui dua indikator yaitu Debt Ratio dan Debt to Equity Ratio. Kuncoro, et al. (2009), Mujianto (2012) dan Kirmizi (2009) melakukan penelitian mengenai transformasi dengan melakukan evaluasi kinerja perusahaan berbasis laporan keuangan tahunan.

Dalam menilai kinerja perusahaan, diperlukan suatu evaluasi bidang keuangan secara time series dan cross section. Perkembangan kinerja secara time series digunakan untuk memprediksi keadaan masa yang akan datang. Evaluasi kinerja keuangan dilakukan dengan mengukur rasio-rasio keuangan diantaranya rasio provitabilitas dan likuiditas (Kesi\& Budiati, 2009). Untuk mengetahui pengaruh kinerja keuangan sebelum dan setelah transformasi, Kirmizi (2009) melakukan pengamatan dengan mengukur rasio profitabilitas dan likuditas, sedangkan Mujiyanto (2012) mengamati delapan indikator rasio keuangann sesuai Keputusan Menteri BUMN Nomor KEP-100/MBU/2002 yaitu rasio provitabilitas (ROE,ROI), Rasio Likuiditas (Cash Rasio, Current Rasio) serta Rasio Aktivitas (Inventory Turn Over, Collection Period,Total Turn Over dan Total Modal Terhadap Aset Sendiri). Pengamatan atas rasio-rasio keuangan juga dilakukan oleh Aprilina (2013) untuk mengetahui adanya pengaruh tiga tahun sebelum dan tiga tahun setelah transformasi (privatisasi) dibeberapa BUMN dengan analisa statistik uji T.

\section{METODE PENELITIAN}

Metode yang digunakan dalam penelitian ini adalah metodekuantitatif dengan pendekatan studi kasus pada PT Berdikari (Persero), yang berlokasi di Jakarta Pusat. Penelitian kuantitatif merupakan studi yang diposisikan sebagai bebas nilai (value free), dengan kata lain penelitian kuantitatif sangat ketat menerapkan prinsip-prinsip objektivitas. Objektivitas itu diperoleh antara lain melalui penggunaan instrumen yang telãh diuji validitas dan reliabilitasnya. Peneliti yang melakukan studi kuantitatif mereduksi sedemikian rupa hal-hal yang dapat membuat bias, misalnya akibat masuknya persepsi dan nilai-nilai pribadi. 
Data yang digunakan dalam penelitian ini adalah data sekunder yang berasal dari Laporan Keuangan Perusahaan tahun 2007-2017 yang diperoleh langsung dari perusahaan. Data sekunder ini merupakan data yang sifatnya mendukung keperluan data primer seperti buku, laporan manajemen perusahaan, annual report dan Rencana Anggaran Kerja Perusahaan (RKAP) yang difokuskan dari tahun 2007-2017.Penelitian ini terdiri dari delapan variabel yang merupakan indikator kinerja keuangan pada masa sebelum transformasi dan sesudah transformasi. Pada Gambar 1 dibawah ini merupakan model penelitian untuk mendiskripsikan pengaruh implementasi transformasi bisnis dengan melakukan komparasi.

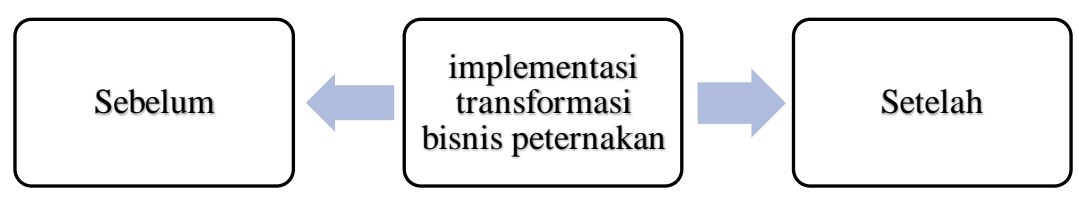

\section{Gambar 1.Model Penelitian}

Uji T berpasangan (Paired T-Test) merupakan uji beda secara parametrik yang menguji adakah perbedaan nilai rata-rata antara 2 kelompok/sampel yang berpasangan (Sugiyono, 2014). Sebelum dilakukan uji beda, data yang diolah harus berdistribusi normal. Adapun rumus uji beda yang digunakan dalam penelitian ini adalaht hitung. Rumus t hitung digunakan ketika standar deviasi sampel atau varian sampel diketahui.

$$
t=\frac{\overline{X_{1}}-\overline{X_{2}}}{\sqrt{\frac{s_{1}^{2}}{n_{1}}+\frac{s_{2}^{2}}{n_{2}}-2 r\left(\frac{s_{1}}{\sqrt{n_{1}}}\right)\left(\frac{s_{2}}{\sqrt{n_{2}}}\right)}}
$$

Keterangan:

$\mathrm{n}=$ Jumlah sampel

$\bar{x}_{1}=$ Rata-rata sampel ke-1

$\bar{x}_{2}=$ Rata-rata sampel ke- 2

$s_{1}^{2}=$ Ragam sampel ke-1

$s_{2}^{2}=$ Ragam sampel ke-2

$\mathrm{n}_{1}=$ Banyaknya sampel ke-1

$\mathrm{n}_{2}=$ Banyaknya sampel ke-2

$\mathrm{r}=$ Korelasi antara 2 sampel

Pengujian hipotesis dilakukan untuk mengetahui pengaruh dari penerapan transformasi tersebut terhadap kondisi keuangan perusahaan. Dilakukan pengukuran delapan indikator kinerja keuangan sebelum dan sesudah penerapan transformasi, sehingga hipotesanya adalah sebagai berikut:

Ho: tidak ada perbedaan kondisi keuangan antara sebelum dan sesudah penerapan transformasi.

H1: ada perbedaan kondisi keuangan antara sebelum dan sesudah penerapan transformasi.

Adapun kriteria pengambilan keputusan dalam pengujian hipotesis ini adalah:

Jika Sig.(p) $>0,05$ maka Ho diterima

Jika Sig.(p) $<0,05$ maka Ho ditolak. 
Tabel 2. Hipotesa dari indikator yang diamati

\begin{tabular}{ll}
\multicolumn{1}{c}{ Rasio } & Hipotesa \\
\hline $\begin{array}{l}\text { Rasio Profitabilitas } \\
\text { Return on Equity }\end{array}$ & \\
Return on investment & Ho : tidak ada perbedaan sebelum dan setelah transformasi \\
Rasio Aktivitas & \\
Inventory Turn Over & \\
Collecting Period & $\mathrm{H} 1:$ ada perbedaan antara sebelum dan setelah transformasi \\
Total Turn Over & \\
Total Modal Terhadap Aset Sendiri & \\
Rasio Likuiditas & \\
Current Ratio & \\
Cash Ratio &
\end{tabular}

Dalam pengolahan data, program komputer yang digunakan adalah Microsoft Excel untuk merekam data yang bersifat ordinal, nominal, interval dan membuat tabulasi silang dan mengoreksi data dan untuk melakukan Uji $\mathrm{T}$ Berpasangan (Paired T-Test) dengan menggunakan SPSS.

\section{HASIL DAN PEMBAHASAN}

Pengolahan data diawali dengan mengukur normalitas data kinerja keuangan. Menurut Ghozali (2013), uji normalitas bertujuan untuk menguji apakah dalam model regresi, variabel pengganggu atau residual memiliki distribusi normal. Jumlah data dalam penelitian ini adalah sebanyak 80 data.Berdasarkan 80 data tersebut diperoleh hasil sebagaimana tercantum dalam Tabel 3 berikut ini:

Tabel 3. Hasil uji normalitas

\begin{tabular}{llccc}
\hline Variabel & Kolmogorov-Smirnov Z & Sig. (2-tailed) & \\
\hline & Pra & Pasca & Pra & Pasca \\
ROE & 0,641 & 0,556 & 0,806 & 0,917 \\
ROI & 0,72 & 0,718 & 0,677 & 0,681 \\
Cash Ratio & 0,589 & 0,68 & 0,879 & 0,745 \\
Current Ratio & 0,85 & 0,377 & 0,466 & 0,999 \\
Collection Period & 0,742 & 0,668 & 0,641 & 0,763 \\
Inventory Turn Over & 0,522 & 0,505 & 0,948 & 0,961 \\
Total Turn Over & 0,667 & 0,463 & 0,764 & 0,983 \\
Total Modal Sendiri Terhadap Asset & 0,636 & 0,663 & 0,813 & 0,772 \\
\hline
\end{tabular}

Sumber: Hasil olah data 2019

Tabel 3 menunjukkan bahwa angka Sig (2-tailed) dalam One-Sample KolmogorovSmirnov Test pada seluruh indikator kinerja keuangan lebih besar dari 0,05. Hasil tersebut menunjukkan seluruh data telah berdistribusi normal sehingga dapat dilakukan pengujian tahap selanjutnya.

\section{Kondisi Sebelum Transformasi (Tahun 2007-2012)}

PT Berdikari (Persero) merupakan perusahaan BUMN yang berdiri sejak tahun 1966 dengan nama PT Pilot Proyek Berdikari (PP). Sejak jaman orde baru PT XYZ Persero telah banyak membantu menyelesaikan proyek-proyek yang sifatnya penugasan dari pemerintah. Pada tahun 2000, perusahaan ini berganti nama menjadi PT Berdikari (Persero), yang bergerak pada bisnis general trading dan logistik. Perdagangan bahan komoditi yang menjadi andalan adalah komoditi pupuk, coklat dan rempah-rempah, serta didukung dengan kegiatan meubel, peternakan dan logistik yang dijalankan oleh anak perusahaan. Pada tahun 2007-2011, kinerja keuangan PT Berdikari (Persero) menunjukkan penurunan yang ditandai dengan menurunnya laba perusahaan sebagaimana dijelaskan dalam Gambar 2. 


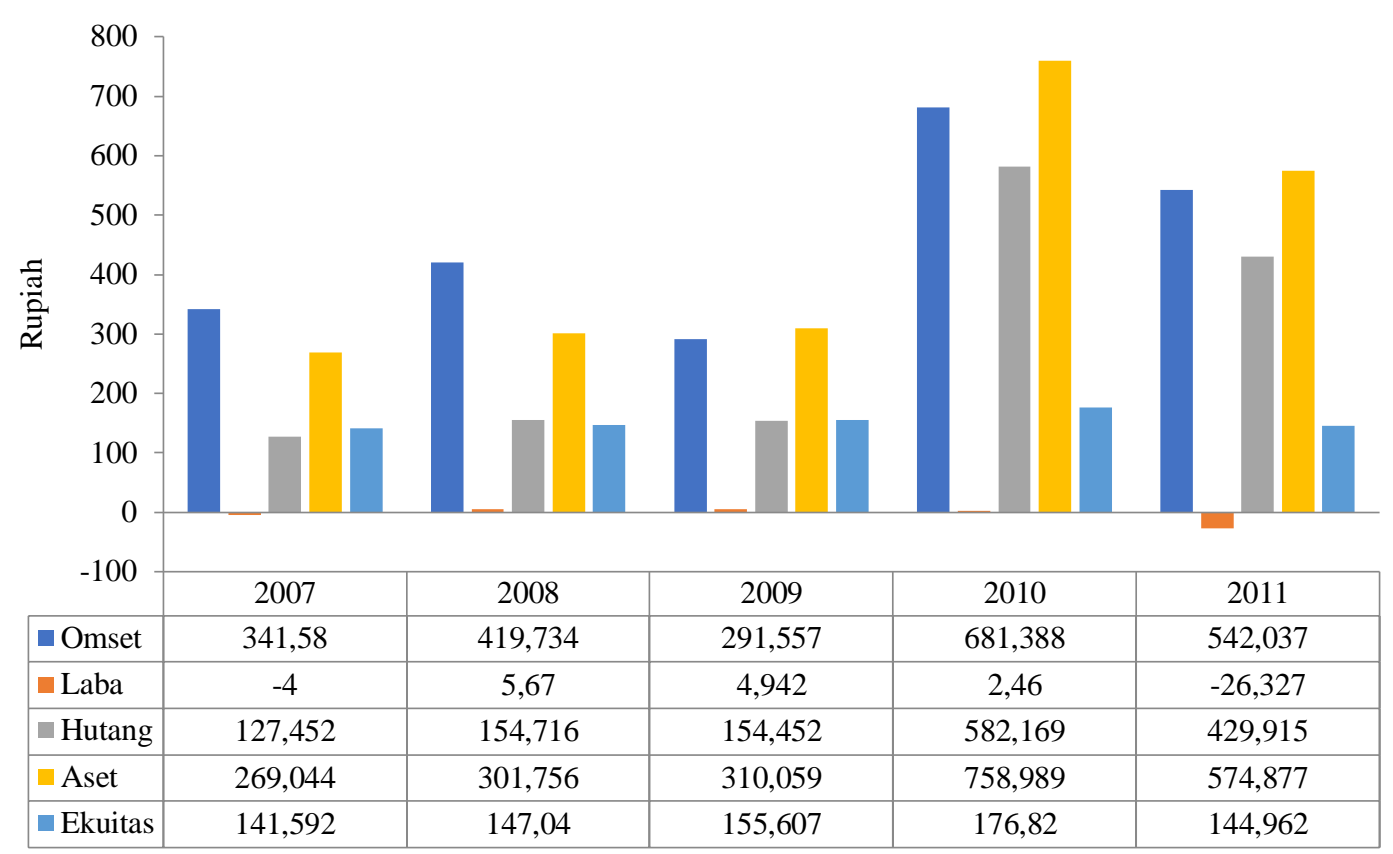

Gambar 2. Kinerja keuangan PT XYZ (Persero)Sebelum Transformasi Bisnis

Gambar 2 menunjukkan penurunan capaian kinerja PT Berdikari (Persero) tahun 2007 sampai dengan tahun 2011. Periode tersebut tergolong masa sebelum transformasi perusahaan. Kementerian BUMN sebagai pemegang saham mendorong perusahaan untuk mencari solusi dan membantu meningkatkan performa perusahaan untuk peningkatan kinerjanya. Ada beberapa hal yang mempengaruhi penurunan kinerja PT Berdikari (Persero) salah satunya adalah semakin banyaknya pesaing baik swasta maupun BUMN yang bergerak di perdagangan komoditi, serta kurang fokusnya pada bisnis yang dijalani, karena terlalu banyak komoditi yang diperdagangkan.Kinerja BUMN yang relatif rendah ini tidak dapat dibiarkan berlarut-larut, karena akan semakin tertinggal dan sulit bersaing dengan perusahaan swasta sejenis. Pengaruh internal juga berkontribusi terhadap penurunan kinerja perusahaan, diantaranya kondisi SDM, terbatasnya modal kerja,dan lemahnya tata kelola perusahaan. Berdasarkan data kepegawaian PT Berdikari (Persero) secara konsolidasi didominasi oleh karyawan yang berpendidikan SLTA, kondisi tersebut menjadi beban bagi perusahaan, khususnya untuk belanja pegawai, namun belum mampu mendukung manajemen dalam mencapai target realisasi yang ditetapkan.

Beberapa langkah telah dilakukan untuk mengatasi keterbatasan modal, salah satunya dengan optimalisasi aset dan meminjam modal dari perbankan. Kondisi infrastruktur yang belum memadai, rendahnya penjualan dan lemahnya tata kelola perusahaan, menyebabkan manajemen tidak dapat menghasilkan cash dalam waktu singkat, ditambah dengan beban bunga yang menumpuk akibat pinjaman perbankan mengakibatkan beban perusahaan semakin bertambah. Upaya optimalisasi aset perusahaan juga telah dilakukan dan cukup membantu dalam mengatasi beban keuangan perusahaan, dengan menyewakan aset-aset yang dimiliki berupa gedung dan bangunan yang tersebar diseluruh Indonesia. Walaupun pendapatan dari optimalisasi aset cukup, namun karena tinggingya beban usaha, beban biaya administrasi dan pegawai serta beban bunga perbankan, maka pendapatan tersebut belum mampu mendorong peningkatan laba perusahaan.

\section{Kinerja Keuangan pada Masa Transformasi}

Dalam rangka mengatasi turunnya kinerja perusahaan, pemerintah perlu melakukan

transformasi (Aprilina, 2013).Transformasi PT Berdikari(Persero) ditandai dengan penguatan peran oleh Kementerian BUMN pada tahun 2012 melalui surat Menteri BUMN Nomor S211/D1.MBU/2012 yang memberikan penugasan dan menunjuk PT Berdikari(Persero) sebagai BUMN Peternakan. Penunjukan tersebut merupakan penugasan strategis untuk membantu dan 
turut serta berkontribusi mensukseskan program pemerintah dalam meningkatkan penyediaan pangan hewani yang aman dan kesejahteraan peternak melalui kebijakan dan program pembangunan peternakan yang berdaya saing dan berkelanjutan dengan mengoptimalkan pemanfaatan sumber daya lokal. Adapun tujuan khusus penugasan ini adalah membantu menjamin ketersediaan benih dan bibit ternak yang berkualitas, meningkatkan populasi dan produktivitas dan meningkatkan serta mempertahankan status kesehatan hewan, jaminan keamanan produk dan meningkatkan pelayanan prima kepada masyarakat. Dengan penugasan ini diharapkan PT Berdikari(Persero) dapat berperan aktif dan membantu meningkatkan kinerja perusahaan.

Implementasi transformasi bisnis menyebabkan terjadinya anomali kinerja keuangan yang ditandai dengan naik turunnya profitabilitas perusahaan. Kondisi tersebut menjadi tantangan dan bahan evaluasi untuk menentukan kebijakan perusahaan pada tahun-tahun mendatang. Penugasan ini memaksa internal perusahaan untuk melakukan transformasi bisnis yang beralih dari bidang perdagangan umum ke bidang peternakan.Perubahan yang terjadi pada organisasi ditimbulkan oleh faktor eksternal dan internal, yang sering kali berinteraksi hingga mereka saling memperkuat satu sama lainnya (Winardi, 2008). Sejumlah faktor yang bersifat spesifik yang menyebabkan organisasi perlu beralih dari kondisi status quo, diantaranya pengaruh dari faktor lingkungan eksternal diantaranya perusahaan harus mengikuti peraturan yang ditetapkan oleh pemerintah. Faktor internal diantaranya dapat disebabkan karena reaksi terhadap dunia luar, dan mereka dianggap sebagai pemicu eksternal (eksternal triggers) dan faktor-faktor tersebut dapat menjadi penghambat maupun pendukung penerapan transformasi perusahaan (Mulyono, 2014).Adapun faktor internal yang menghambat transformasi bisnis adalah kebijakan pemberdayaan (empowerment) melalui perubahan struktur organisasi belum berjalan efektif serta upaya meningkatkan brand image perusahaan melalui modernisasi fisik belum tercapai secara optimal, serta reputasi perusahaan yang kurang baik dibandingkan perusahaan pesaing. Sedangkan faktor pendukung keberhasilan transformasi diantaranya konektivitas, kepemilikan aset yang besar, dukungan pemerintah (Mujiyanto,2012).

Tahap analisis selanjutnya yaitu pengujian hipotesis dengan uji beda rata-rata dua sampel independen. Pengujian ini sejalan dengan hipotesis penelitian yang bertujuan untuk membuktikan apakah terdapat perbedaan kinerja keuangan periode tahun 2007-2011 dengan periode tahun 2013-2017. Pengujian hipotesis menggunakan uji t dengan tingkat signifikansi 95 persen. Hasil uji t tercantum pada Tabel 4.

Tabel 4. Hasil Uji Beda (Uji t)

\begin{tabular}{lrrrr}
\hline \multicolumn{1}{c}{ Variabel } & Sebelum & Sesudah & \multicolumn{1}{c}{ Thit } & Sig* \\
\hline ROE & $(1,768)$ & 26,416 & 10,492 & 0,012 \\
ROI & 4,254 & $(8,738)$ & 1,151 & 0,315 \\
Cash Ratio & 34,046 & 17,992 & 0,101 & 0,759 \\
Current Ratio & 167,492 & 98,106 & 0,176 & 0,686 \\
Collection Periode & 114,318 & 272,666 & 3,920 & 0,083 \\
Inventory Turn Over & 55,374 & 89,576 & 7,995 & 0,022 \\
Total Turn Over & 111,640 & 58,108 & 0,050 & 0,828 \\
Total Modal Sendiri & 40,474 & 10,720 & 3,807 & 0,088 \\
\hline
\end{tabular}

*taraf kepercayaan 95\% $(\alpha=0,05 \%)$

Tabel 4 menunjukkan bahwa skor sig (2-tail) untuk variable ROE dan Inventory Turn Over adalah di bawah 0,05 yang berarti Ho ditolak. Hal tersebut menunjukkan bahwa terdapat perbedaan ROEdanInventory Turn Overantara sebelum dan sesudah transformasi. Adapun gambaran kondisi ROE dan Inventory Turn Over sebelum dan sesudah transformasi perusahaan diringkas penyajiannya dalam Gambar 3. 


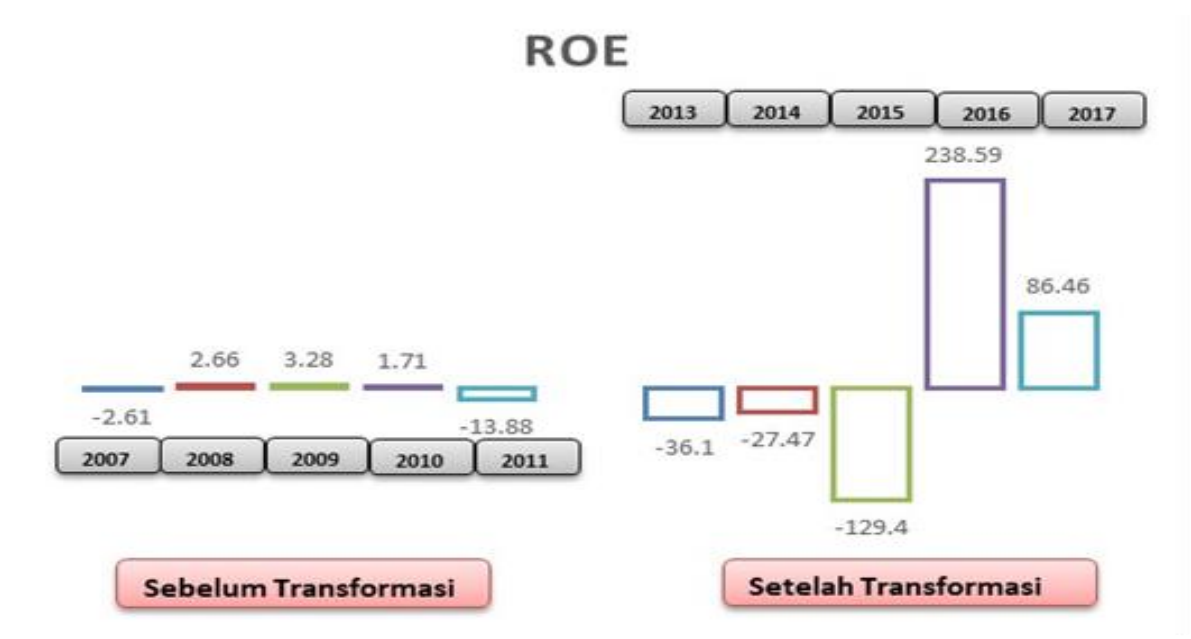

Gambar 3. Capaian ROE sebelum dan sesudah penerapan transformasi bisnis Sumber: Laporan keuangan PT Berdikari Persero

Kinerja keuangan setelah implementasi transformasi bisnis belum banyak berubah, yang ditandai dengan semakin menurunnya laba perusahaan dari 32,6 miliar (2013) menjadi minus 7,63 miliar ditahun 2017. Peningkatan ROE pada tahun 2013-2017 terjadi karena akumulasi rugi akibat menghadapi masalah dan tantangan besar baik dari internal maupun eksternal perusahaan. Permasalahan internal diantaranya kondisi SDM dan rendahnya penjualan. Kondisi internal yang menjadi persoalan adalah aspek psikologis dan semangat karyawan yang menurun, ketidakmampuan untuk bersaing, tidak produktif dan lemah dalam pemasaran, buruknya reputasi serta lemahnya pengendalian internal.

Permasalahan eksternal yang diidentifikasi antara lain adalah persaingan ketat dalam bisnis peternakan, serta dominasi pemain lama yang menguasai pasar peternakan. Berikutnya adalah tidak terealisasinya impor sapi serta daging sapi karena kurangnya permodalan serta tingginya biaya produksi serta operasional di perusahaan. Tingginya biaya perusahaan ini merupakan akibat dari masih belum tersedianya sarana prasarana/fasilitas infrastruktur peternakan sapi sehinggamenambah beban perusahaankarena perusahaan harus menyewa infrastruktur peternakan diantaranya adalah sewa kandang untuk fattening sapi dan peternakan ayam. Faktor internal tersebut menunjukkan bentuk pengelolaan perusahaan BUMN yang tidak efisien. Sistem pengelolaan perusahaan yang tidak efisien dapat menyebabkan perusahaan tidak mampu meningkatkan efisiensi (cenderung terjadi pemborosan dalam hampir segala bidang dalam perusahaan) dan akhirnya berdampak kepada rendahnya daya saing perusahaan (Kirmizi, 2009).

Proses transformasi PT Berdikari (Persero) menunjukkan dinamika yang menarik karena dibalik ancaman dan tantangan yang dihadapi seiring perkembangan zaman dan teknologi serta perubahan regulasi, perusahaan ini tetap dibutuhkan. Hal ini terkait peran PT Berdikari(Persero) yang merupakan entitas bisnis yang bermotif ekonomi, namun disisi lain juga mengemban misi membantu mensejahterakan masyarakat melalui dukungannya sebagai salah satu BUMN pangan di bidang peternakan.Transformasi yang diimplementasikan oleh PT Berdikari (Persero) pada tiga tahun pertama setelah transformasi belum menunjukkan hasil peningkatan kinerja, bahkan sebaliknya terjadi akumulasi rugi, pada tahun 2017 kondisi kinerja keuangan mulai membaik. Menurut Aprilina (2013) dalam penelitiannya melakukan pengamatan transformasitiga tahun sebelum dan tiga tahun setelah transformasi belum dapat menunjukkan perubahan pada perusahaan dalam meningkatkan keuntungan dari modal dan aset yang dimilikinya.

Gambar 3menunjukkan Return on Equity (ROE) atau imbalan kepada pemegang saham, yang menunjukkan bahwa nilai ROE sangat fluktuatif. Masa sebelum implementasi transformasi yakni tahun 2007 nilai ROE minus 2,61, tahun 2008-2010 meningkat hingga 1,71 dan kembali menurun ditahun 2011 menjadi minus 13,88.Denganimplementasi transformasi 
bisnis,nilai ROE cenderung meningkat, terutama di tahun 2016. Nilai ROE yang cukup tinggi di tahun 2016, diantaranya disebabkan oleh peningkatan laba serta peningkatan kontribusi modal yang dapat meningkatkan laba perusahaan. Hal tersebut menunjukkan bahwa pertumbuhan ekuitas belum maksimal meningkatkan laba perusahaan. Pelemahan kemampuan menghasilkan laba yang ditunjukkan dengan penuruan nilai ROE perlu menjadi perhatian bagi manajemen karena merupakan indikator penilaian kinerja keuangan dengan nilai terbesar sesuai peraturan Menteri BUMN Nomor: KEP-100/MBU/2002 tentang penilaian Tingkat Kesehatan Badan Usaha Milik Negara. Kondisi ini sesuai dengan hasil penelitian Pujiastutiet al. (2018) tentang kinerja Perum Perikanan Indonesia periode 2013-2017 yang menunjukkan hasil bahwa ROE pada tahun 2013 mencapai 22,90 persen namun terus menurun hingga hanya mencapai 2 persen pada tahun 2017. Demikian pula dengan hasil penelitian Iswahyudi et al. (2014) tentang kinerja keuangan periode 2012 hingga 2014 di PG Djatiroto yang merupakan salah satu unit usaha PTPN XI. Dari sisi profitabilitas, PG Djatiroto mengalami penurunan nilai ROE karena laba perusahaan terus berkurang. Hal tersebut disebabkan oleh tidak maksimalnya kualitas gula yang dihasilkan karena bahan baku tebu kurang baik dan umur mesin dan peralatan pabrik yang sudah tua.

Pengaruh implementasi transformasi bisnis berdasarkan penelitian Kirmizi (2009), yang meneliti sembilan perusahaan BUMN yang melakukan transformasi bisnis dengan hasil penelitian yang menunjukkan bahwa terdapat tiga perusahaan BUMN yang mengalami peningkatan rasio Return of Equity (ROE) setelah perusahaan mengalami transformasi (privatisasi) seperti PT.Telkom, PT. Timah, PT. Aneka Tambang. Sementara enam perusahaan lainnya mengalami penurunan rasio ROE. Hal tersebut bermakna bahwa keenam perusahaan telah mengalami penurunan terhadap kontribusi modal sendiri untuk menghasilkan laba.Dari penelitian tersebut dapat disimpulkan bahwa program transformasi (privatisasi) tidak berpengaruh untuk meningkatkan rasio ROE pada perusahaan BUMN.

Indikator keuangan berikutnya yang menunjukkan perbedaan kondisi pada periode tahun 2007-2011dibandingkan dengan periode tahun 2012-2017 yaitu Inventory Turn Over atau perputaran persediaan. Indikator tersebut pada periode 2007-2011 cenderung stabil. Sebaliknya, pada periode tahun 2012-2017 mengalami fluktuasi. Kondisi anomali terjadi pada tahun 2015 dengan nilai terendah seperti tercantum pada Gambar 4.

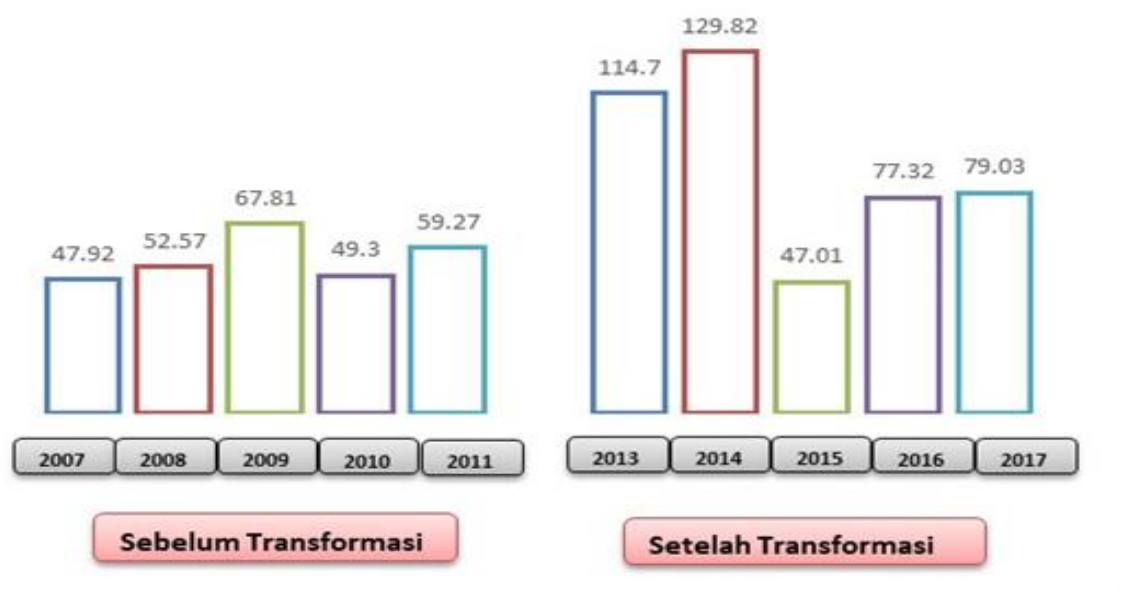

Gambar 4. Perbandingan InventoryTurn Over tahun 2007-2011 dengan tahun 2013-2017 (dalam satuan hari).

Sumber: Laporan keuangan PT XYZ Persero

Gambar 4menunjukkan bahwa sejak implementasi transformasi bisnis diterapkan perkembangan rasio keuangan perusahaan dari aspek aktivitas(Inventory Turn Over)relatif meningkat. Rata-rata nilai indikator tersebut pada periode tahun 2013-2017 meningkat dibandingkan periode tahun 2007-2011. Pada tahun 2007 nilai Inventory Turn Over 47,92 meningkat menjadi 67,81 pada tahun 2009 dan melambat hingga 59,27 di tahun 2011. Setelah 
implementasi transformasi bisnis, nilai perputaran persediaan meningkat di dua tahun pertama menjadi 129,82 di tahun 2014. Perputaran persediaan pada tahun 2014 mencapai titik tertinggi yaitu 129 hari, hal ini terjadi karena pada tahun 2014perusahaan merugi dan akibat menurunnya omset penjualan, sehingga barang persediaan belum didistribusikan dan masih banyak yang menumpuk digudang penyimpanan. Tingginya stok daging yang tersimpan dalam jumlah banyak digudang, tidak mampu diolah karena kurangnya modal kerja, serta banyaknya sapi di Ranch yang tidak mampu dioptimalkan dengan baik, sehingga menyebabkan tingginya biaya perawatan sapi dan beban biaya pegawai/karyawan yang menjaga sapi dan juga mengamankan lahan Ranch yang banyak diserobot oleh warga.

Kondisi tersebut menunjukkan sinyal kurang baik bagi kesehatan keuangan perusahaan. Semakin lama waktu perputaran persediaan maka penanaman modal dalam persediaan semakin lama dan lambat diubah menjadi kas. Hasil penelitian Rahayu dan Joni (2014) menunjukkan variabel perputaran persediaan menunjukkan pengaruh positif secara parsial terhadap profitabilitas.

\section{KESIMPULAN}

Implementasi transformasi bisnis peternakan berpengaruh signifikan terhadap indikator ROE dan Inventory Turn Over, yang ditandai dengan masih rendahnya nilai ROE dan tingginya nilai Inventory Turn Over. Hal ini menunjukkan bahwa penerapan core bisnis baru peternakan belum dapat menngkatkan laba perusahaan yang disebabkan diantaranya oleh faktor dukungan pemodalan dan sumberdaya manusia. Rendahnya penjualan produk, tingginya beban usaha dan lamanya perputaran persediaan menunjukkan belum optimalnya pengelolaan perusahaan. Penerapan transformasi masih butuh proses panjang yang perlu mendapatkan dukungan dari semua pihak.

Penelitian ini diharapkan dapat menjadi bahan masukan dalam menentukan langkahlangkah untuk mengoptimalkan dan efektifitas pelaksanaan penerapan transformasi bisnis di perusahaan, dalam rangka meningkatkan kinerja perusahaan. Selain itu dapat menjadi bahan pertimbangan bagi pemerintah khususnya Kementerian BUMN sebagai pemegang saham dalam merencanakan, mengambil keputusan dan membuat kebijakan tentang penerapan transformasi bisnis di perusahaan BUMN maupun swasta.

\section{DAFTAR PUSTAKA}

Aprilina, V.(2013). Dampak Privatisasi Pada Kinerja Keuangan BUMN. Jurnal Akuntansi Volume 4 No 1 (1:12).Fakultas Ekonomi.Unisma.Bekasi.

Dibyo, S. (2004). Refleksi BUMN 1993-2003. Yogyakarta: Media Pretindo.

Ghozali, I. (2013). Aplikasi Analisis Multivariate dengan Program IBM SPSS21 Update PLS Regresi. Semarang: Badan Penerbit Universitas Diponegoro.

Iswahyudi, D. M. P., Dwiatmanto, \&Devi, F.(2014). Analisis Tingkat Kesehatan Perusahaan Berdasarkan Keputusan Menteri BUMN Nomor: KEP-100/MBU/2002 (Studi Kasus pada Pabrik Gula Djatiroto Lumajang Periode 2012-2014). Jurnal Administrasi Bisnis (JAB), 33(1), 98-104.

Kesi, W.,\& Budiati, Y.(2009). Kinerja Keuangan Sektor Telekomunikasi di Indonesia.Jurnal Dinamika Sosbud, 2(2), 139-154.

Kirmizi. (2009). Analisis Perusahaan BUMN Sebelum dan Sesudah Privatisasi di Indonesia. Jurnal Ilmu Administrasi Negara, 9(2), 103-113.

Kuncoro, M., Tandelilin, E., Ancok, D., Basuki, H., Purbasari, D. P., Adji, A., Wulandaru, D. R.,Junarsin, E., Purwoto, H., Sulistyaningrum, E., Fitradi,A. (2009). Transformasi Pertamina: Dilema antara Orientasi Bisnis dan Pelayanan Publik. Yogyakarta: Galang Press

Mujiyanto. (2012). Analisis Penerapan Transformasi Bisnis: Studi Pada PT Pos Indonesia (Persero) Tahun 2012. Yogyakarta: Universitas Gajah Mada.

Mulyadi. (1997). Akuntansi Manajemen: Konsep, Manfaat dan Rekayasa. Edisi 8. 
Yogyakarta: STIE-YKPN

Mulyadi.(2009). Akuntansi Biaya. Yogyakarta: STIE-YKPN.

Nurpratama, M. R.(2016). Pengaruh Knowledge Manajemen Terhadap Kinerja Karyawan PT PLN Distribusi Jawa Timur. Jurnal Unair, 5(3), 41-42.

Pujiastuti, L., Muhammad, F., \&Deni, A. (2018). Portofolio dan Kinerja Bisnis Perikanan Tangkap (Kasus di Perum Perikanan Indonesia). Jurnal Albacore. 2(2): 161-171.

Rahayu, E. A., \&Joni, S. (2014). Pengaruh Perputaran Kas, Perputaran Piutang dan Perputaran Persediaan terhadap Profitabilitas Perusahaan Manufaktur. Jurnal Ilmu Manajemen, 2(4), 1444-1455.

Ristandi, D. K.(2013).Kajian Transformasi Perusahaan: Studi pada PT Telekomunikasi Indonesia Tbk. Yogyakarta: Universitas Gajah Mada.

Sarkar, S.(2013). The Art of Business Transformation. Paper value 6. Issue 2013.

Syamsudin, L. (2009). Manajemen Keuangan Perusahaan (Konsep Aplikasi Dalam Perencanaan Pengawasan Dan Pengambilan Keputusan). Jakarta: Penerbit PT. Raja Grafindo Persada. 